\title{
Description of a new species of Colaxes Simon, 1900 (Araneae: Salticidae: Ballinae) from the tropical montane cloud forests of Western Ghats, India
}

\author{
Описание нового вида Colaxes Simon, 1900 (Araneae: Salticidae: \\ Ballinae) из вмахкных тропических горных месов Западных Гатов, \\ ИнаИя
}

\author{
Jimmy Paul ${ }^{1, *}$, Dhruv A. Prajapati², Mathew M. Joseph ${ }^{1}$, \\ Pothalil A. Sebastian ${ }^{1}$ \\ Ажимми Пом ${ }^{1, *}$, Ахрув А. Праджапати ${ }^{2}$, Матью М. Ажкосе $\phi^{1}$, \\ Поталиц А. Себастьян ${ }^{1}$
}

\footnotetext{
${ }^{1}$ Division of Arachnology, Department of Zoology, Sacred Heart College, Thevara, Cochin, Kerala 682 013, India.

${ }^{2}$ GEER Foundation, Indroda Nature Park, Gandhinagar, Gujarat 382007, India.

"Corresponding author. E-mail: jimmypaul88@gmail.com
}

KEY WORDS: Aranei, Chikmagalur, jumping spider, high altitude, shola forests.

КЛЮЧЕВЫЕ СЛОВА: Aranei, высокогорье, колковые леса, паук-скакунчик, Чикмагалур.

ABSTRACT. A new species Colaxes sazailus sp.n. is described from South India. A detailed description, diagnostic features and illustrations of both sexes are given. The collecting localities of all the Colaxes species from South Asia are updated and mapped.

How to cite this article: Paul J., Prajapati D.A., Joseph M.M., Sebastian P.A. 2020. Description of a new species of Colaxes Simon, 1900 (Araneae: Salticidae: Ballinae) from the tropical montane cloud forests of Western Ghats, India // Arthropoda Selecta. Vol.29. No.2. P.244-250. doi: 10.15298/arthsel. 29.2.10

РЕЗЮМЕ. Описан новый вид Colaxes sazailus sp.n. из Индии. Приводятся детальные описания, диагнозы и иллюстрации обоих полов. Точки находок всех видов Colaxes из южной Азии уточнены и прокартированы.

\section{Introduction}

The salticid genus Colaxes was erected by Simon [1900] on the basis of the male specimen collected from Tiruchirappilly (formerly Trichinopoly), Tamil Nadu, India. Recently, Benjamin [2004] revised the genus, suggested the balline phylogeny based on morphological characters and described two new species from Sri Lanka; he also proposed some apomorphic characters for the genus based on Colaxes wanlessi Benjamin, 2004. The genus' range was extended to the Ethiopian Region after the description of Colaxes benjamini Wesołowska et Haddad, 2013 and a transfer of Homalattus insularis Peckham et Peckham, 1885 to
Colaxes [Wesołowska, 2019]. Currently, the genus Colaxes consists of five valid species [WSC, 2020]. However, the female of the generotype Colaxes nitidiventris Simon, 1900 and the male of $C$. horton Benjamin, 2004 remain unknown yet. In the present paper, we diagnose and describe a new Colaxes species from the tropical montane cloud forests of Western Ghats, India.

\section{Materials and Methods}

All measurements are in $\mathrm{mm}$. The length of palps and leg segments is given as follows: total (femur, patella, tibia, metatarsus [except for palps], tarsus). The format of spine position on tibiae follows Benjamin [2004]. Images of preserved specimens were taken with a Leica DMC2900 digital camera attached to a Leica M205A stereomicroscope, with the software package Leica Application Suite (LAS, version 4.5.0) for stacking images taken at different focal planes. Scanning electron (SEM) micrographs were taken by means of JEOL JSM-6390LV. The studied specimens are deposited in the reference collection of the Division of Arachnology, Department of Zoology, Sacred Heart College, Thevara, Cochin, Kerala, India (ADSH). Abbreviations used in the text are as follows: ALE - anterior lateral eye, AME anterior median eye, PLE - posterior lateral eye, PME posterior median eye, RTA - retrolateral tibial apophysis, I-IV -1 st to 4 th leg.

\section{Taxonomy}

Colaxes Simon, 1900

Type species: Colaxes nitidiventris Simon, 1900, by the original designation [Simon, 1900]. 

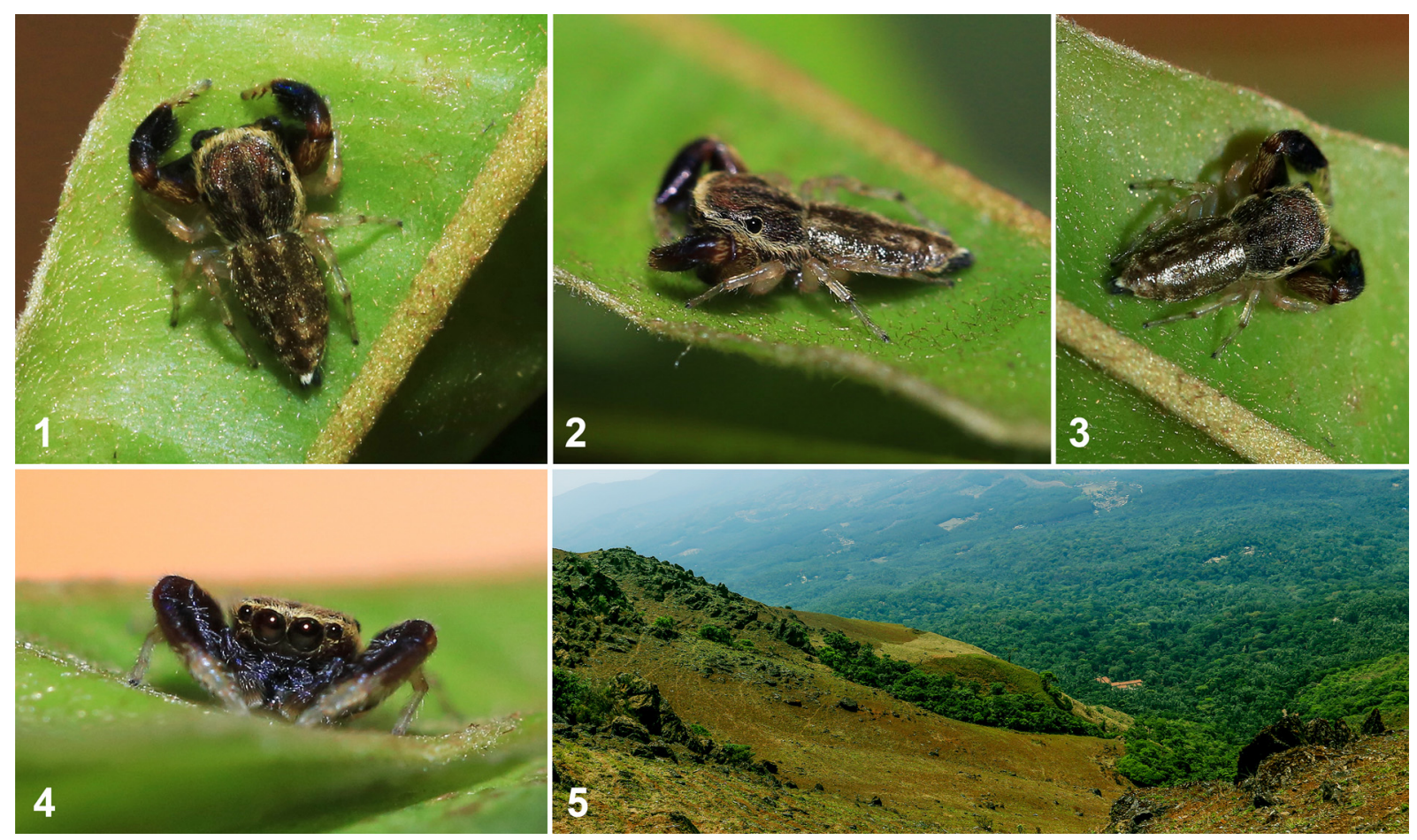

Figs 1-5. Live males of Colaxes sazailus sp.n. (ADSH831205A; 1-4) and the tropical montane cloud forests in Mulayanagiri (5).

Рис. 1-5. Живые самцы Colaxes sazailus sp.n. (ADSH831205A; 1-4) и влажные тропические горные леса в Мулаянагири (5).

DIAGNOSIS. Colaxes can be distinguished from all the Ballinae by the following characters: dark lateral markings of the abdomen on yellow background (Figs 6, 15), the absence of dark markings on lateral sides of legs II-IV (Figs 6-8) and four fused retromarginal teeth (cf. figs 35-37 with those on p. 16 in Prószyński [1987]).

COMMENTS. The diagnostic characters of the genus suggested by Benjamin [2004] such as the dark lateral markings of the abdomen and the absence of dark markings on the lateral sides of legs I-IV are absent from the African representatives of Colaxes [Wesołowska, Haddad, 2013; Wesołowska, 2019]. Although dark transverse and lateral patches on the abdomen could be noticeable in C. benjami$n i$, those patterns are different from the dark lateral markings seen in the Asian species (cf. figs 4-5, 16 in Wesołowska \& Haddad [2013] and figs 11A, 12A, 13A, E, 16A in Benjamin [2004]).

This type of ambiguity in diagnostic character definition could also be seen in the absence of lateral markings on legs I-IV. The femur and tibia of leg I of almost all Colaxes species (unknown in C. nitridventris and C. horton) are generally darker than other legs and hence any specific dark markings might be indistinguishable in the normal dark background of femur and tibia I. A light shade on legs of $C$. insularis (see figs 1-3 in Wesołowska [2019]) retains the vagueness of this character in long-term poorly preserved specimens. However, the uncertainty of both these diagnostic characters still remains in the African species and even in the Asian species to a lesser extent. Except for these two diagnostic characters, all other characters of Colaxes are nearly identical with those of Marengo and Ballus. Thus, a taxonomic validity of Colaxes itself requires a further investigation, ideally on the basis of a DNA-based approach.

\section{Colaxes sazailus sp.n. \\ Figs 1-37, Map.}

TYPE. HolotyPe $\mathrm{O}^{7}$ (ADSH831205A) from India, Karnataka, Chikmagalur, Mulayanagiri Peak $\left(13^{\circ} 23^{\prime} 27.19^{\prime \prime} \mathrm{N}, 75^{\circ} 43^{\prime} 16.79^{\prime \prime} \mathrm{E}\right)$, $1892 \mathrm{~m}$ a.s.1., hand collecting, 22.04.2017, J. Paul \& S.M. Prashanthakumara. Paratypes: 1 ( (ADSH831205C), together with the holotype.

ETYMOLOGY. The specific epithet is an adjective in the Sanskrit language referring to the nature of the type locality; sazaila means mountainous.

DIAGNOSIS. The males of C. sazailus sp.n. can be distinguished from those of $C$. nitidiventris by following combination of characters: dorsum with two laterally elongated dark bands and without a transverse white line (Figs $1-3,6,8)$ vs lateral dark bands with a transverse white line in the centre of dorsum in $C$. nitidiventris (cf. fig. $11 \mathrm{~A}$ in Benjamin [2004]; p. 16 in Prószyński [1987]); tibiae with three spines (Fig. 28) vs tibiae with five spines (see p. 16 in Prószyñski [1987]); tegulum with an obtuse extended lobe (Figs 10-12, 24-26) vs tegulum with a pointed extended lobe (cf. fig. 11B-C in Benjamin [2004]; p. 16 in Prószyński [1987]). The females can be separated from those of all the other South Asian congeners by the following characters: the bilobed epigynal septum, the presence of a gland of the copulatory atrium and the reduced translucent septum (Figs $19,22-23,34)$.

DISTRIBUTION. Only the type locality (Map).

HABITAT. All specimens were collected from small patches of the tropical montane cloud forests (shola forests) in southern Western Ghats (Fig. 5).

DESCRIPTION. MaLe (holotype, Figs 1-5, 6-14, 24 25, 33; paratype, 26-32). Colouration of Live specimens: 

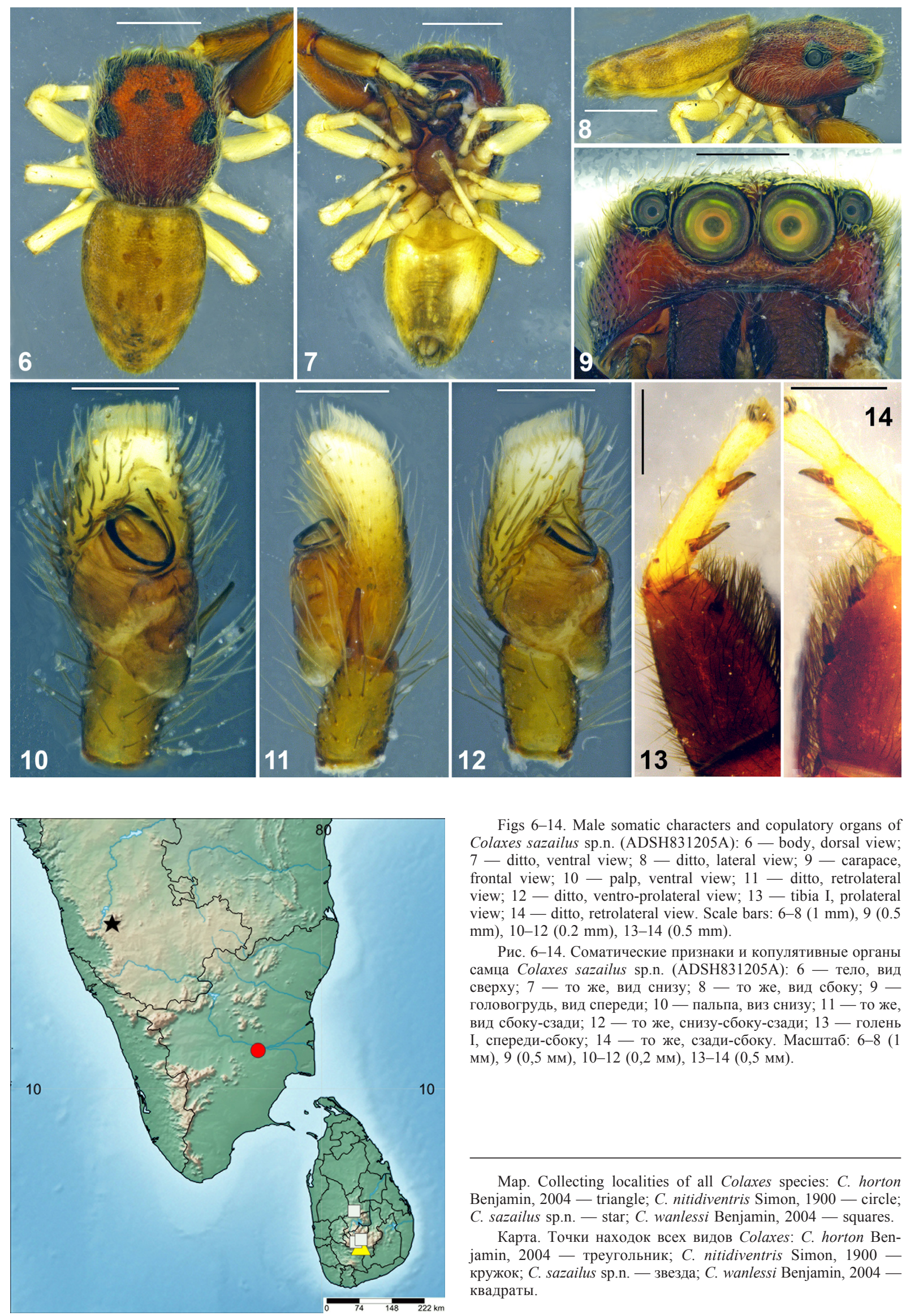

Figs 6-14. Male somatic characters and copulatory organs of Colaxes sazailus sp.n. (ADSH831205A): 6 - body, dorsal view; 7 - ditto, ventral view; 8 - ditto, lateral view; 9 - carapace, frontal view; 10 - palp, ventral view; 11 - ditto, retrolateral view; 12 - ditto, ventro-prolateral view; 13 - tibia I, prolateral view; $14-$ ditto, retrolateral view. Scale bars: $6-8(1 \mathrm{~mm}), 9(0.5$ $\mathrm{mm}), 10-12(0.2 \mathrm{~mm}), 13-14(0.5 \mathrm{~mm})$.

Рис. 6-14. Соматические признаки и копулятивные органы самца Colaxes sazailus sp.n. (ADSH831205A): 6 - тело, вид сверху; 7 - то же, вид снизу; 8 - то же, вид сбоку; 9 головогрудь, вид спереди; 10 - пальпа, виз снизу; 11 - то же, вид сбоку-сзади; 12 - то же, снизу-сбоку-сзади; 13 - голень I, спереди-сбоку; 14 - то же, сзади-сбоку. Масштаб: 6-8 (1 мм), 9 (0,5 мм), 10-12 (0,2 мм), 13-14 (0,5 мм).

Map. Collecting localities of all Colaxes species: C. horton Benjamin, 2004 - triangle; C. nitidiventris Simon, 1900 - circle; C. sazailus sp.n. - star; C. wanlessi Benjamin, 2004 - squares.

Карта. Точки находок всех видов Colaxes: C. horton Benjamin, 2004 - треугольник; C. nitidiventris Simon, 1900 кружок; C. sazailus sp.n. — звезда; C. wanlessi Benjamin, 2004 квадраты. 

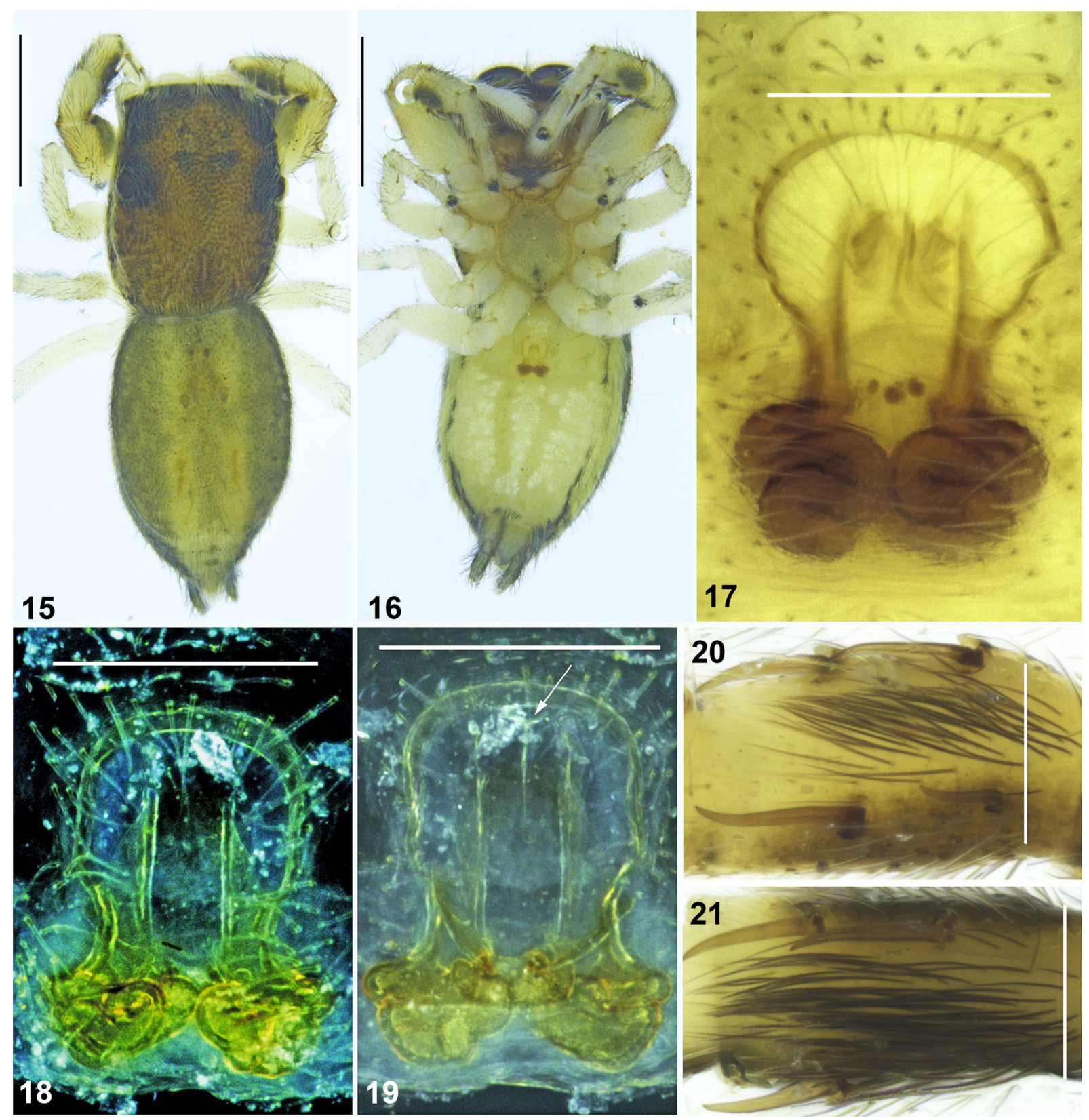

Figs 15-21. Female somatic characters and copulatory organs of Colaxes sazailus sp.n.: 15 - (ADSH831205B), body, dorsal view; 16 - ditto, ventral view; 17 - (ADSH831205C), epigyne, ventral view; 18 - (ADSH831205B), ditto, ventral view; 19 - ditto, dorsal view, the bilobed epigynal septum is arrowed; 20 - tibia I, ventral view; 21 - (ADSH831205C), ditto, ventral view. Scale bars: $15-16$ (1 $\mathrm{mm}), 17-21(0.2 \mathrm{~mm})$.

Рис. 15-21. Соматические признаки и копулятивные органы самки Colaxes sazailus sp.n.: 15 - (ADSH831205B), тело, вид сверху; 16 - то же, вид снизу; 17 - (ADSH831205C), эпигина, вид снизу; 18 - (ADSH831205B), то же, вид снизу; 19 - то же, вид сверху, двулобый эпигинальный септум помечен стрелкой; 20 - голень I, снизу; 21 - (ADSH831205C), то же, снизу. Масштаб: $15-16$ (1 мм), 17-21 (0,2 мм).

carapace anterior and lateral margins covered with ivory setae, cephalic region dark reddish brown; thorax medially with a pair of longitudinal thin parallel lines covered with ivory setae; abdomen black, with two lateral and one median elongated black bands separated by longitudinal parallel lines which extend from the thorax (Figs 1-5). Colouration IN ALCOHOL. Strongly flattened body. Carapace oval, slightly longer than wide; cephalic region reddish orange, with two irregular black patches medially; thoracic and lateral regions reddish brown; margins dark brown. Slightly granulated carapace, with short white hairs along with scattered long white hairs and long brown hairs near eyes. Abdomen oval, thin, longer than wide; dorsum light yellow, with two laterally elongated pale grey bands; venter with a median grey band and white markings. Spinnerets pale brown. Chelicerae, endites, labium and sternum light brown. Chelicerae with four small, fused retromarginal teeth (Figs 35-37). Sternum oval, with dark anterior margins. Leg I dark brown 


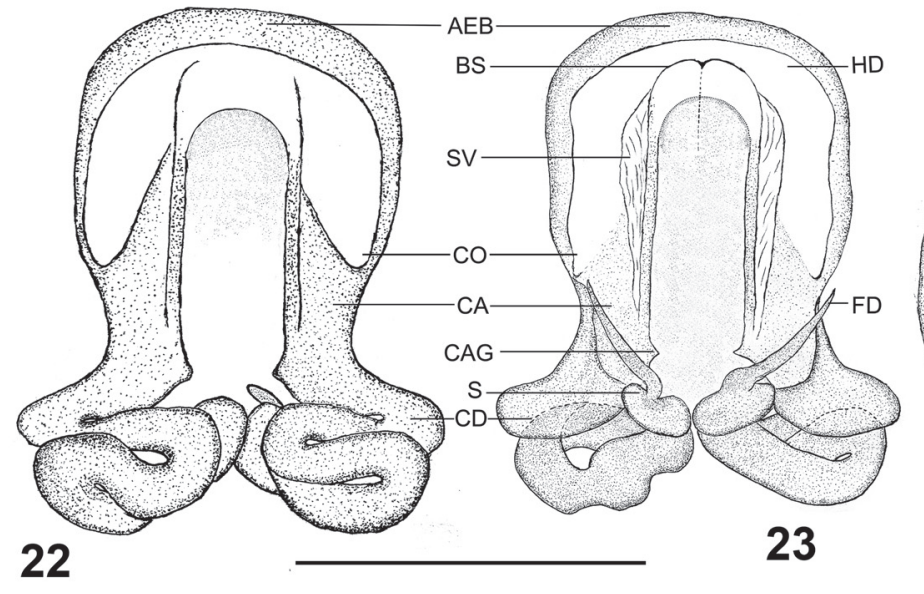

24

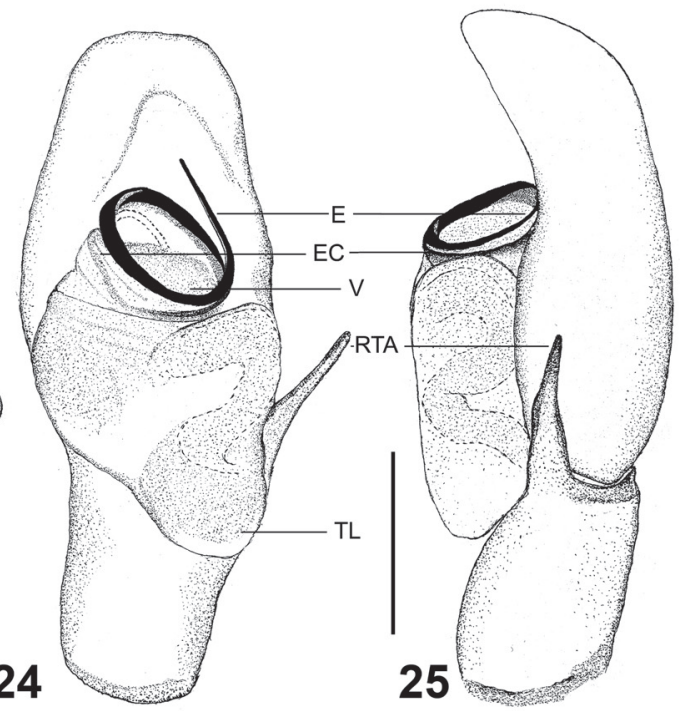

Figs 22-25. Copulatory organs of Colaxes sazailus sp.n.: 22 - (ADSH831205B), epigyne, ventral view; 23 - ditto, dorsal view; 24 (ADSH831205A), male palp, ventral view; 25 - ditto, retrolateral view. Abbreviations: AEB — anterior epigynal border, BS - bilobed epigynal septum, CA - copulatory atrium, CAG — gland of copulatory atrium, CD - copulatory duct, CO - copulatory opening, E embolus, EC - embolic coil, FD - fertilization duct, HD — horseshoe-shaped depression, RTA — retrolateral tibial apophysis, S spermathecae, TL - tegular lobe, SV — translucent septum, V — velum. Scale bars: 22-25 (0.2 mm).

Рис. 22-25. Копулятивные органы Colaxes sazailus sp.n.: 22 - (ADSH831205B), эпигина, вид снизу; 23 - то же, вид сверху; 24 - (ADSH831205A), пальпа самца, вид снизу; 25 - то же, вид сбоку-сзади. Сокращения: AЕВ - передний эпигинальный край, $\mathrm{BS}$ - двулобый эпигинальный септум, CA — копулятивный атриум, CAG — железа копулятивного атриума, CD - копулятивный проток, СО - копулятивное отверстие, E - эмболюс, EC - петля эмболюса, FD - осеменительный каналец, НD подковообразное вдавление, RTA - ретролатеральный тибиальный отросток, S - сперматека, TL — тегулярная доля, SV прозрачный септум, V - велум. Масштаб: 22-25 (0,2 мм).

and enlarged except for metatarsus and tarsus. Remaining legs pale yellow, without lateral markings. Femur I with two short dorsal spines and a single long seta, tibia I with three ventral spines and without any leaf like scales $(0 / 0 / 1 / 2)$; metatarsus I with two pairs of ventral spines (2/2); femur IV with three long macrosetae dorsally; proximal and distal long setae on all patellae dorsally; long spine-like dense hairs around metatarsi III-IV distally. Body length 4.97. Carapace length 2.34, width (at the middle) 2.34, height (at the middle) 0.75. Abdomen length 2.63, width (at the middle) 1.92. Eye diameter: ALE 0.22, AME 0.54, PLE 0.28, PME 0.08. Eye interdistances: AME-AME 0.03, AMEALE 0.04, ALE-ALE 1.18, ALE-PME 0.20, PLE-PLE 1.59, PME-PME 1.51, PME-PLE 0.43. Clypeus height at ALE 0.44 , at AME 0.12. Chelicera length 0.64. Measurements of palp and legs. Palp $2.11(0.93,0.35,0.23,0.60)$, I 4.47 $(1.64,0.55,1.12,0.83,0.33)$, II $3.11(1.09,0.45,0.60,0.64$, $0.32)$, III 2.95 (1.00, 0.40, 0.54, 0.68, 0.33), IV 3.61 (1.29, $0.46,0.77,0.76,0.33)$. Leg formula: 1423 . Palp as in Figs 10-12, 24-25, 26-27, 31-33: segments brown, cymbium apical end broad; bulbus bilobed, pear-shaped in the ventral view; RTA long, apical half bent with a pointed tip; tegulum extending above tibia, sperm duct question mark-shaped in the ventral view; embolus short, coils 1.5 times.

Female (paratype, Figs 15-20, 22-23, 34). Colouration IN ALCOHOL. In all details like the male, except as follows: less colourful than the male; tibia I with two pairs of ventral spines $(0 / 0 / 2 / 2)$; all femora with three long setae dorsally; all tibiae except for tibia III and IV with a median long seta dorsally. Body length 4.16. Carapace length 1.85 , width (at the middle) 0.47 , height (at the middle) 0.76. Abdomen length 2.31, width (at the middle) 1.57. Eye diameter: ALE
0.17, AME 0.42, PLE 0.22, PME 0.08. Eye interdistances: AME-AME 0.03, AME-ALE 0.02, ALE-ALE 0.93, ALEPME 0.21, PLE-PLE 1.23, PME-PME 1.14, PME-PLE 0.26. Clypeus height at ALE 0.22, at AME 0.05. Chelicera length 0.38 . Measurements of palp and legs. Palp $1.22(0.54$, $0.11,0.24,0.33)$ I $2.67(0.90,0.44,0.56,0.42,0.35)$, II 2.04 $(0.75,0.27,0.44,0.30,0.28)$, III $2.29(0.74,0.32,0.44$, $0.48,0.31)$, IV $3.16(1.05,0.48,0.65,0.64,0.34)$. Leg formula: 4132. Epigyne (Figs 17-19, 22-23, 34): the anterior epigynal border without a tooth, making a large anterior horseshoe-shaped depression; spermathecae heavily sclerotized; copulatory openings relatively large, lying mediolaterally; translucent septum thin, reduced (Figs 23, 34); a sclerotized bilobed septum lying in close contact with the translucent septum (Figs 19, 23); copulatory atria long; gland of the copulatory atrium short, conical, arising at its base, confronting each other; copulatory ducts with s-shaped convolution ventrally; fertilization duct long; spermathecae small, bean-shaped, lying diagonally (Figs 19, 23).

VARIATION. Female specimens showed a slight variation with regard to the number of spines on tibia I. Out of the three studied females, two (ADSH831205C) have three spines on tibiae and one (ADSH831205B) four spines.

Acknowledgements. We are grateful to Rev. Fr. Prasanth Palackappillil CMI, the Principal of the Sacred Heart College, Thevara, Cochin for providing us with all the facilities for completing this research. Many thanks go to Mr. Prashanthakumara S.M. for his valuable field support, Dr Pradeep M. Sankaran for his generous help and to Mr Karunnappilli S. Nafin for his suggestions and constant support to materialize this manuscript. Thanks to Dr Charles Haddad 

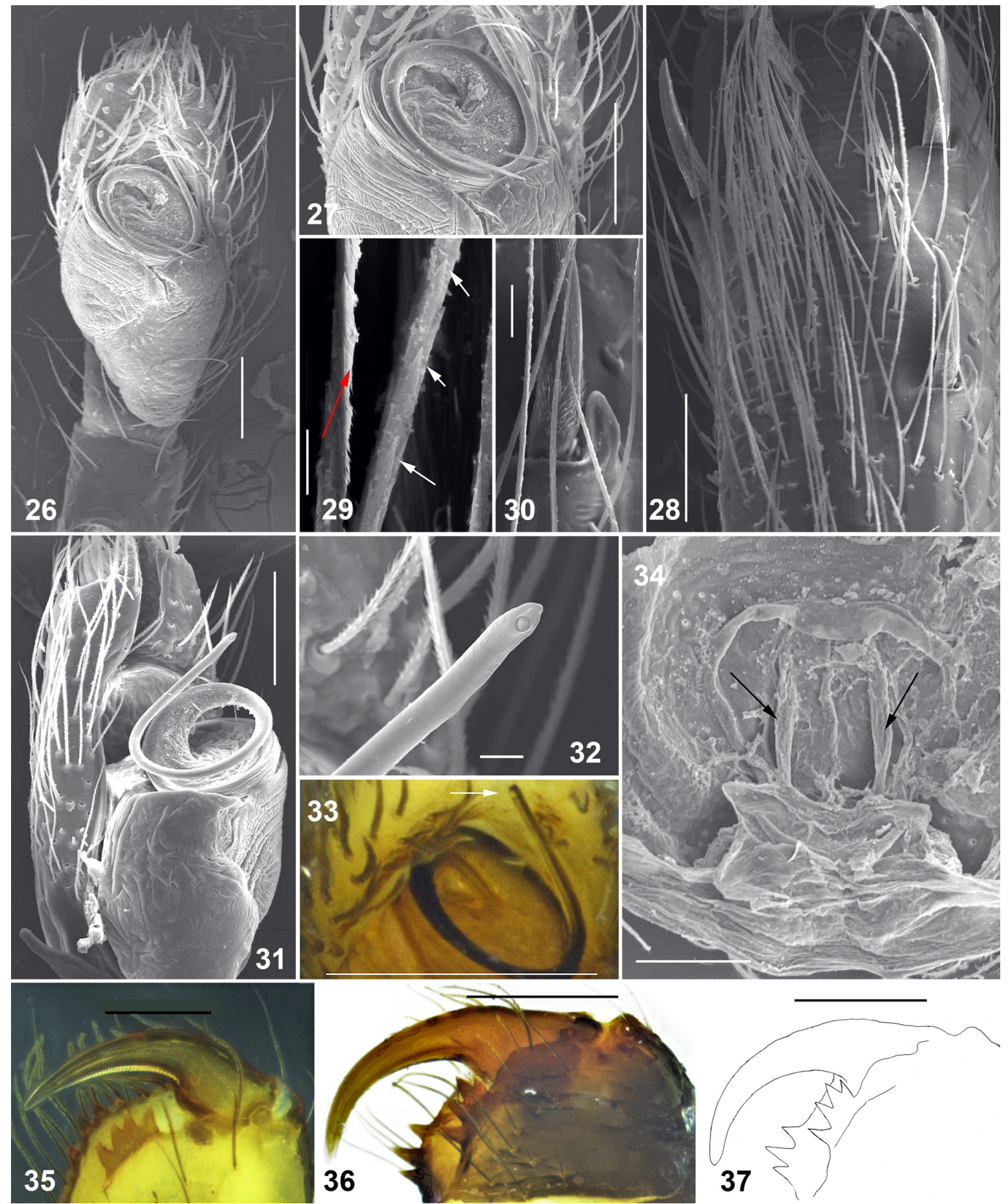

Figs 26-37. Somatic characters and copulatory organs of Colaxes sazailus sp.n., ADSH831205C (26-32, 34), ADSH831205A (33, 36, 37), ADSH831205B (35): 26 - male palp, ventral view; 27 - embolic division; 28 - male tibia I, ventral view; 29 - setae on male tibia I, red arrow points to plumose setae, white arrow points to spine-like projections on setae; 30 — base of the male tibial spine; 31 male palp, ventro-retrolateral view; 32 - embolic tip; 33 - embolus; 34 - epigyne, dorsal view, arrows point to translucent septae; 35 female left chelicerae, retrolateral view; 36-37 - male left chelicerae, retrolateral view. Scale bars: $26-28,31,34(0.1 \mathrm{~mm}), 29(5 \mu \mathrm{m}), 30$ $(20 \mu \mathrm{m}), 32(10 \mu \mathrm{m}), 33,35-37(0.2 \mathrm{~mm})$

Рис. 26-37. Соматические признаки и копулятивные органы Colaxes sazailus sp.n., ADSH831205C (26-32, 34), ADSH831205A (33, 36, 37), ADSH831205B (35): 26 — пальпа самца, вид снизу; 27 — эмболярный отдел; 28 — голень I самца, вид снизу; 29 щетинка на голени I самца, красная стрелка показывает перистые щетинки, белые стрелки показывают шипообразные выросты щетинки; 30 - основание тибиального шипа самца; 31 - пальпа самца, вид снизу-сзади-сбоку; 32 - кончик эмболюса; 33 эмболюс; 34 - эпигина, вид снизу, стрелка показывает прозрачные септы; 35 - левая хелицера самки, вид сбоку-сзади; 36-37 левая хелицера самца, вид сбоку-сзади. Масштаб: 26-28, 31, 34 (0,1 мм), 29 (5 мкм), 30 (20 мкм), 32 (10 мкм), 33, 35-37 (0,2 мм). 
(UFS, South Africa) and Dr Suresh Benjamin (NIFS, Sri Lanka) for the suggestions. We are indebted to Dr Dmitri Logunov (Manchester, UK) for providing suggestions and editing the ms. We are especially thankful to the Science and Engineering Research Board (SERB)-DST, New Delhi for providing funding support under the Major Research Project No. SB/SO/AS/094/2013.

\section{References}

Benjamin S.P. 2004. Taxonomic revision and a phylogenetic hypothesis for the jumping spider subfamily Ballinae (Araneae, Salticidae) // Zoological Journal of the Linnaean Society. Vol.142. P.1-82.

Prószyński J. 1987. Atlas rysunków diagnostycznych mniej znanych Salticidae 2 // Zeszyty Naukowe Wyższej Szkoly RolniczoPedagogicznej v Siedlcach. P.1-172.
Simon E. 1900. Descriptions d'Arachnides nouveaux de la famille des Attidae // Annales de la Société entomologique de Belgique. T.44. P.381-407.

Wesołowska W., Haddad C.R. 2013. New data on the jumping spiders of South Africa (Araneae: Salticidae) // African Invertebrates. Vol.54. P.177-240. doi:10.5733/afin.054.0111

Wesołowska W. 2019. Colaxes insularis (Peckham \& Peckham, 1885 ) is a valid species of jumping spiders (Araneae: Salticidae: Ballinae) // Israel Journal of Entomology Vol.49. No.1. P.57-61. doi: $10.5281 /$ zenodo.3539465

WSC 2020. World Spider Catalog. Natural History Museum Bern, online at http://wsc.nmbe.ch, version 20.0. (accessed on $27^{\text {th }}$ February 2020).

Responsible editor D.V. Logunov 